\title{
PARTISIPASI MASYARAKAT LOKAL DALAM PENGEMBANGAN DESA WISATA CARANGSARI
}

\section{COMMUNITY PARTICIPATION IN DEVELOPMENT OF CARANGSARI TOURISM VILLAGE}

\author{
Dewa Putu Bagus Pujawan Putra \\ Kementerian Pariwisata \\ E-mail: novebsmp@gmail.com
}

\begin{abstract}
The study aims to analyze community participation in the development of Carangsari Tourism Village in Petang District, Badung Regency. This research uses qualitative analysis where data are obtained through observation, interview, documentation, literature study and Focus Group Discussion with Badung Regency government, community leaders in Carangsari, academicians and practitioners in the field of tourism village. The research showed the community participation was in the form of a false and passive consultation, minimum community participation and only economic benefit was gained. Factors that influence the low participation were divided into internal factors namely the understanding of tourism village, tourism village management bodies, human resources and mapping of the village's excellent products. Meanwhile, external factors were the study of tourism village, funding sources and community empowerment programs and marketing. The current model of participation leads to the top down while alternative models are offered incorporating the ideas from the community with the government and academicians in developing local potentials into natural and cultural tourism attractions managed by the Tourism Village Management Board in the hope of providing economic welfare, cultural revitalization and environmental conservation. The novelty in this study is not all community members participate in the tourism village. Therefore, it is necessary to evaluate the tourism villages.
\end{abstract}

Keywords: community participation, community-based tourism, tourism village, sustainable tourism

\begin{abstract}
ABSTRAK
Penelitian ini dilakukan dengan tujuan menganalisis partisipasi masyarakat lokal dalam pengembangan Desa Wisata Carangsari di Kecamatan Petang, Kabupaten Badung. Pengumpulan data dilakukan dengan menggunakan pendekatan kualitatif. Data diperoleh melalui observasi, wawancara, dokumentasi, studi literatur dan Focus Group Discussion dengan pemerintah Kabupaten Badung, tokoh masyarakat Desa Wisata Carangsari, akademisi, dan praktisi di bidang desa wisata. Hasil penelitian menunjukkan bentuk partisipasi masyarakat adalah consultation dengan sifat semu dan pasif, masyarakat minim partisipasi dan dan hanya memperoleh manfaat ekonomi. Faktor yang memengaruhi rendahnya partisipasi masyarakat terbagi dalam dua faktor, yaitu faktor internal dan faktor eksternal. Faktor internalnya meliputi pemahaman desa wisata, badan pengelola desa wisata, sumber daya manusia, dan pemetaan produk unggulan desa, sementara faktor eksternal berupa kajian desa wisata, sumber dana dan program pemberdayaan masyarakat serta pemasaran. Saat ini, model partisipasi masyarakat mengarah pada top down. Sementara itu, metode alternatif menawarkan gagasan agar masyarakat bersama pemerintah dan akademisi turut berpartisipasi mengembangkan potensi lokal menjadi daya tarik wisata alam dan budaya yang dikelola Badan Pengelola Desa Wisata. Harapannya dengan begitu mampu bermanfaat bagi kesejahteraan ekonomi, revitalisasi budaya lokal, dan konservasi lingkungan. Unsur kebaruan dalam penelitian ini adalah tidak semua desa wisata memiliki masyarakat yang ikut berpartisipasi sehingga perlu dilakukan evaluasi terhadap desa wisata.
\end{abstract}

Kata kunci: partisipasi masyarakat, pariwisata berbasis masyarakat, desa wisata, pariwisata berkelanjutan 


\section{PENDAHULUAN}

Pariwisata, yang saat ini berada pada posisi keempat sebagai penyumbang PDB (Produk Domestik Bruto) Indonesia, diharapkan dapat berkontribusi lebih dengan ditetapkannya sebagai sektor unggulan dan menjadi core business untuk Indonesia. Fenomena ini menjadikan pariwisata sebagai suatu bidang yang sentral di Indonesia, bahkan di dunia melalui laporan dari United Nations of World Tourism Organization (UNWTO)Tourism Highlights 2016 yang menunjukkan pertumbuhan terbesar, yakni 6\%, terjadi di Asia dan Pasifik. Pariwisata juga menyumbangkan $10 \%$ dari PDB (Produk Domestik Bruto) dunia serta memberikan 1 dari 11 lapangan kerja di dunia. Pada tahun 2019, Kementerian Pariwisata telah menargetkan 20 juta wisatawan mancanegara. Untuk mencapai itu maka dilakukan sejumlah terobosan dalam bidang kepariwisataan. Rapat Koordinasi Nasional II pada 19 Mei 2017 telah mengkhususkan membahas mengenai desa wisata sebagai salah satu bentuk pariwisata alternatif, dengan eskalasi program unggulan Kementerian Pariwisata pada digitalisasi, konektivitas udara dan homestay.

Untuk lebih mengembangkan pariwisata di Indonesia dan mengejar target kunjungan wisatawan mancanegara ke Indonesia, pemerintah mengembangkan 10 destinasi "Bali Baru". Penggunaan kata "Bali" dimaksudkan sebagai magnet untuk menarik wisatawan berkunjung ke sepuluh destinasi wisata lainnya di Indonesia, yaitu Danau Toba di Sumatera Utara, Tanjung Kelayang di Bangka Belitung, Tanjung Lesung di Banten, Kepulauan Seribu di DKI Jakarta, Borobudur di Jawa Tengah, Bromo Tengger Semeru di Jawa Timur, Mandalika di Nusa Tenggara Barat, Labuan Bajo di Nusa Tenggara Timur, Wakatobi di Sulawesi Tenggara, dan Pulau Morotai di Maluku Utara. Kata Bali digunakan karena pulau ini telah mendapatkan pengakuan internasional sebagai salah satu destinasi wisata terbaik 2017 oleh Trip Advisor.

Bali sendiri terdiri dari delapan kabupaten dan satu kota, yaitu Kabupaten Badung, Kabupaten Tabanan, Kabupaten Jembrana, Kabupaten Buleleng, Kabupaten Karangasem, Kabupaten Bangli, Kabupaten Klungkung, Kabupaten
Gianyar, dan Kota Madya Denpasar. Kesembilan daerah ini telah mengembangkan desa wisata yang berdasarkan data dari Dinas Pariwisata Provinsi Bali terdapat 180 desa wisata. Munculnya fenomena pariwisata alternatif serta idealisme agar masyarakat lokal tidak menjadi penonton membuat desa wisata berkembang, yang diharapkan kue pariwisata sampai ke desa. Pariwisata yang berkembang di Bali selama ini terpusat di Kabupaten Badung, sekaligus menjadikannya kabupaten terkaya di Bali. Namun, hal ini tidak membuat Kabupaten Badung hanya menikmati pariwisatanya yang berpusat di selatan. Selain itu, Kabupaten Badung juga mengembangkan 11 desa wisata untuk mengimbangi ketimpangan di Badung Utara, Badung Tengah, dan Badung Selatan.

Adapun ke-11 desa wisata tersebut, yaitu Desa Wisata Bongkasa Pertiwi, Desa Wisata Pangsan, Desa Wisata Kerta, Desa Wisata Pelaga, Desa Wisata Belok, Desa Wisata Carangsari, Desa Wisata Sangeh, Desa Wisata Baha, Desa Wisata Kapal, Desa Wisata Mengwi, dan Desa Wisata Munggu. Di antara desa-desa wisata tersebut, Desa Wisata Carangsari menjadi lokus penelitian karena desa tersebut merupakan tempat kelahiran pahlawan nasional I Gusti Ngurah Rai dan banyak aktivitas pariwisata yang berkembang, seperti menunggangi gajah, rafting, dan outbound. Aktivitas wisata yang terbilang sangat berkembang tersebut tidak diimbangi dengan partisipasi masyarakat lokal, tetapi didominasi oleh pihak swasta.

Mengingat partisipasi masyarakat merupakan salah satu kunci dari desa wisata maka penelitian ini terfokus pada bentuk, proses dan manfaat partisipasi, faktor-faktor yang memengaruhi rendahnya partisipasi serta model partisipasi masyarakat lokal dalam pengembangan Desa Wisata Carangsari di Kecamatan Petang, Kabupaten Badung. Beberapa penelitian telah mengkaji untuk menemukan pemecahan masalah di Desa Wisata Carangsari.

Nalayani (2015) dalam tesisnya meneliti tentang "Evaluasi dan Strategi Pengembangan Desa Wisata di Kabupaten Badung, Bali". Penelitian tersebut melihat 11 desa wisata di Kabupaten Badung yang dievaluasi melalui skala peringkat 
tiga dan merumuskan strategi pengembangannya melalui analisis SWOT. Hasilnya menunjukkan dari sebelas desa wisata tersebut terdapat dua desa wisata yang sudah berkembang (Desa Wisata Sangeh dan Desa Wisata Bongkasa Pertiwi), satu desa wisata belum berkembang (Desa Wisata Lawak), dan delapan desa wisata kategori sedang berkembang (Desa Wisata Mengwi, Desa Wisata Kiadan Pelaga, Desa Wisata Carangsari, Desa Wisata Pangsan, Desa Wisata Baha, Desa Wisata Munggu, Desa Wisata Petang, dan Desa Wisata Kapal). Hasil evaluasi dan strategi pengembangan khususnya Desa Wisata Carangsari tersebut akan digunakan sebagai masukan dalam penelitian ini dan dipadupadankan dengan hasil di lapangan. Menurut Nalayani, Desa Wisata Carangsari mempunyai panorama alam desa yang mengagumkan, sanggar tari dan tabuh, atraksi gajah serta Monumen I Gusti Ngurah Rai. Rencana strategis untuk desa wisata kategori sedang berkembang, yaitu diversifikasi produk wisata, pengelolaan desa wisata yang lebih serius, pemertahanan budaya yang unik, peningkatan kualitas sumber daya manusia (SDM), peningkatan kerjasama antar-sektor pendukung pariwisata, peningkatan promosi serta pemberdayaan masyarakat dalam meningkatkan keamanan lingkungan.

Kajian yang dilakukan oleh Salleh, Shukor, Othman, Samsudin, dan Idris (2015) berjudul "Factors of Local Community Participation in Tourism-Related Business: Case of Langkawi Island" meneliti faktor-faktor yang memengaruhi partisipasi masyarakat Langkawi dalam pembangunan pariwisata. Wawancara dan kuesioner dipergunakan dalam penelitian ini. Data diolah menggunakan Statistical Package for the Social Science (SPSS) dan Analysis of Moment Structure (AMOS). Hasil dari penelitian tersebut mengindikasikan ada dua faktor yang memengaruhi partisipasi masyarakat dalam pembangunan pariwisata yakni tingkat pendapatan dan dukungan dari keluarga. Faktor tersebut juga didukung dengan faktor lainnya, yaitu kepercayaan diri, kepentingan, dan ketersedian peluang di Langkawi. Hasil penelitian ini akan digunakan untuk menambah pembahasan dalam penelitian dan cara pandang yang disesuaikan dengan kenyataan di lapangan.
Hasil Penelitian Ziku (2015) di Desa Komodo terkait "Partisipasi Masyarakat Desa Komodo dalam Pengembangan Ekowisata di Pulau Komodo" mengungkap bentuk-bentuk partisipasi masyarakat, faktor pendorong dan penghambat partisipasi serta dampak dari partisipasi masyarakat terhadap pengembangan ekowisata di Pulau Komodo. Hasil penelitian tersebut menunjukkan bahwa partisipasi masyarakat menimbulkan dampak positif terhadap ekonomi, lingkungan, serta sosial budaya. Dampak positif tersebut akan menjadi tambahan dalam mengungkap manfaat yang diperoleh masyarakat dari partisipasi yang dilakukan di desa Carangsari.

Yulianie (2015) dalam penelitian yang berjudul "Partisipasi dan Pemberdayaan Masyarakat dalam Pengelolaan Daya Tarik Wisata 'Rice Terrace' Ceking, Gianyar, Bali” menemukan bahwa terdapat dua masyarakat yang berada pada atraksi wisata Ceking yakni masyarakat Tegallalang dan masyarakat Kedisan. Kedua masyarakat tersebut berpartisipasi dengan baik namun pemberdayaan masyarakat di Kedisan masih belum optimal.

Pada tahun 2014 di Kenya dilakukan penelitian oleh Wanga, Hayombe, Agong, dan Mossberg (2014) dengan judul "Stakeholder Involvement in Tourism Destination Development: A Case of Dunga Beach and Wetland, Kisumu Country, Kenya". Penelitian ini mendeskripsikan tentang pendekatan sistem partisipasi untuk pengembangan pariwisata pada pemangku kepentingan di Pantai Dunga dan Wetland. Penelitian tersebut menghasilkan rekomendasi berupa kapasitas ruang, kebijakan, perencanaan serta investasi guna mendukung fasiliatas kepariwisataan. Hasil ini akan dipergunakan dalam penelitian di Desa Carangsari sebagai tambahan pada kesimpulan dan saran terkait partisipasi.

Maneenetr, Naipinit, dan Tran (2014) di Thailand melakukan kajian berjudul "Guidelines to Promote Local Community Participation in Developing Agrotourism: A Case Study of Ban Mor Village, Sam Sung District, Khon Kaen Province, Thailand". Hasilnya menunjukkan bahwa untuk mempromosikan partisipasi masyarakat lokal dalam pengembangan agrotourism dibutuhkan promosi, peningkatan fasilitas lokal, penyediaan pusat pembelajaran tentang pertanian 
lokal, pembangunan jaringan agrotourism, dan keterlibatan generasi muda.

Neumeier dan Pollermann (2014) melakukan penelitian dengan judul "Rural Tourism as Promoter of Rural Development - Prospects and Limitations: Case Study Findings from A Pilot Project Promoting Village Tourism". Penelitian dilaksanakan di enam lokasi di Jerman, yakni Brunnharts-hausen, Glaisin, Kladen, Lawalde, Schlieben, dan Gesamt untuk menemukan model promosi desa wisata yang perlu dilakukan agar desa wisata yang akan dikembangkan menjadi sukses. Hasil penelitian menunjukkan terdapat enam faktor kunci kesuksesan desa wisata, yaitu, 1) komitmen para pelaku desa wisata, 2) kemampuan para pelaku desa wisata, 3) struktur organisasi desa wisata, 4) kualitas konsep desa wisata, 5) tingkat penerimaan dan kerjasama dalam desa, dan 6) akses untuk sumber daya permodalan.

Fahmi, dkk. (2013) meneliti tentang "Involvement in Agro Tourism Activities among Communities in Desa Wawasan Nelayan Villages on the East Coast of Malaysia", dengan tujuan mengetahui tingkat partisipasi komunitas nelayan dalam agrotourism. Hasil penelitian menunjukkan tingkat partisipasi nelayan hanya pada level moderat.

\section{TEORI DAN METODE PENELITIAN}

Penelitian ini menggunakan konsep partisipasi masyarakat, desa wisata, pengembangan desa wisata, dan pariwisata berbasis masyarakat. Partisipasi masyarakat yang dimaksud dalam penelitian ini adalah masyarakat lokal yang tinggal pada suatu desa/tempat berperan aktif dalam kegiatan dan usaha pariwisata sehingga menerima manfaat secara langsung serta ikut dalam perencanaan, pelaksanaan pembangunan, pengelolaan dan evaluasi desa wisatanya. Desa wisata adalah suatu tempat dengan batas-batas administratif yang memiliki daya tarik wisata alam-budaya ataupun buatan dengan fasilitas seperti homestay dan kuliner yang dikelola oleh masyarakat lokal. Konsep tersebut kemudian digunakan pada pariwisata berbasis masyarakat sebagai pedomannya serta didukung dengan beberapa teori, sebagai berikut.
Teori Ladder of Citizen Participation milik Arnstein (1969) digunakan untuk meneliti bentuk dalam setiap proses partisipasi masyarakat lokal beserta manfaatnya. Teori tersebut membagi bentuk partisipasi dalam delapan bentuk, yaitu

\section{a. Manipulation}

Pada bentuk ini, masyarakat diharapkan hanya mengikuti apa saja yang diberikan oleh penguasa yang dalam hal ini adalah pemerintah. Hal ini membuat bentuk ini dikategorikan sebagai non-participation.

\section{b. Therapy}

Bentuk selanjutnya, masyarakat dibimbing oleh pemerintah yang membuat mereka menjadi ketergantungan sehingga memiliki mental block untuk mandiri. Permasalahan yang sepenuhnya dihadapi oleh pemerintah seperti orang tua yang menjaga bayi. Bentuk ini juga tergolong non-participation

c. Informing

Masyarakat mulai memahami apa yang menjadi hak dan kewenangan mereka, tetapi komunikasi masih terjadi satu arah antara pemerintah dan masyarakat. Mereka masih belum memiliki kemampuan untuk bernegosiasi sehingga manfaat yang mereka peroleh tergolong kecil. Bentuk ini mulai mengarah pada partisipasi nyata.

\section{d. Consultation}

Pada bentuk ini masyarakat mulai didengarkan ide dan opininya. Mulai terjadi pertemuan antara pemerintah dan masyarakat dalam diskusi maupun rapat. Komunikasi terjadi dua arah dan langkah partisipasi semakin nyata, tetapi dalam bentuk ini partisipasi baru sebatas pencitraan yang realisasi ide dari masyarakat belum tentu terwujud.

\section{e. Placation}

Masyarakat diberikan suatu kekuasaan yang sah dan dapat membuat rencana kegiatan sendiri yang tentunya melalui persetujuan pemerintah. Hal ini seperti dibentuknya organisasi, badan ataupun lembaga di desa oleh pemerintah. 


\section{f. Partnership}

Bentuk ini pemerintah bekerja sama dengan masyarakat dan pendapat serta ide mereka didengarkan dan mulai direalisasikan dalam program kerja sehingga kebutuhan dari masyarakat dapat terwujud. Bentuk ini seperti Memorandum of Understanding (MoU) dengan lembaga terkait untuk mengembangkan Desa Wisata Carangsari.

\section{g. Delegated Power}

Masyarakat mulai dapat bernegosiasi dengan pemerintah serta keputusan ada di tangan masyarakat. Melalui Undang-Undang Desa Nomor 6 Tahun 2014 hal ini dapat terwujud. Namun, kenyataan di lapangan sering kali berbeda terutama di Desa Carangsari yang dana pengelolaan desanya berbeda dengan dana pengelolaan desa wisata sehingga sedikit menghambat pengembangannya.

h. Citizen Control

Bentuk ini mencirikan masyarakat yang sudah mandiri yang mampu mengelola daerah atau desa dengan manajemen sendiri tanpa intervensi dari pihak lain

Teori selanjutnya Irritation Index oleh Doxey's (1975), dipergunakan untuk melihat apakah masyarakat lokal menerima kedatangan wisatawan dan pariwisata sebagai bagian dalam menganalisis faktor-faktor yang mempengaruhi partisipasi masyarakat lokal. Teori ini mengklasifikasikan indeks penerimaan masyarakat terhadap pariwisata menjadi empat bagian yaitu

a. Euphoria

Tahapan ini menunjukkan keadaan masyarakat yang sangat menerima kehadiran pariwisata dan tidak banyak terjadi kontak dengan wisatawan. Masyarakat melihat wisatawan sebagai sebuah peluang usaha. Tahapan ini biasanya ditemukan pada awal pengembangan pariwisata.

\section{b. Apathy}

Pada tahapan ini masyarakat sudah mulai melakukan kontak langsung dengan wisatawan. Wisatawan menjadi sasaran keuntungan (profit taking). Kegiatan pariwisata berkembang dan mampu memberi dampak pada pertumbuhan ekonomi masyarakat

c. Annoyance

Wisatawan mulai banyak berdatangan dan pembangunan secara masif dilaksanakan. Masyarakat mulai terganggu dengan adanya pembatasan ruang dan aktivitas serta munculnya permasalahan akibat berkembangnya pariwisata

\section{d. Antagonism}

Masyarakat menyuarakan ketidaksukaan dan menganggap pariwisata adalah akar permasalahan, tidak hanya dalam bentuk verbal tapi juga perlawanan akan adanya pariwisata.

Teori dari Butler (1980) yang dikenal dengan Tourism Area Life Cycle digunakan untuk melihat pada posisi apa Desa Wisata Carangsari dapat menyusun model partisipasi yang tepat. Teori ini membagi pengembangan destinasi pariwisata dalam tujuh tahapan, yakni.

a. Exploration adalah tahapan mulai ditemukannya daerah tujuan wisata baru yang dikunjungi secara terbatas dan sporadis khususnya bagi wisatawan petualang. Pada tahap ini terjadi kontak yang tinggi antara wisatawan dengan masyarakat lokal karena wisatawan menggunakan fasilitas lokal yang sudah tersedia. Pada tahap ini, dampak sosial-budaya dan sosial-ekonomi masih kecil karena jumlah wisatawan yang terbatas dan frekuensi yang jarang.

b. Involvement adalah tahapan yang ditandai dengan meningkatnya jumlah kunjungan sehingga sebagian masyarakat lokal mulai menyediakan berbagai fasilitas yang memang khusus diperuntukkan bagi wisatawan. Kontak antara wisatawan dengan masyarakat lokal masih tinggi dan masyarakat sudah mulai mengubah pola-pola sosial yang ada untuk merespons perubahan ekonomi yang terjadi. Pada tahap ini lah suatu daerah mulai menjadi destinasi wisata yang ditandai dengan adanya advertensi atau promosi.

c. Development adalah tahapan mulai masuknya investasi dari luar serta mulai munculnya pasar pariwisata secara sistematis. Daerah 
semakin terbuka secara fisik, dan advertensi (promosi) semakin intensif, fasilitas lokal sudah tersisih atau digantikan oleh fasilitas yang benar-benar touristik dengan standar internasional, dan atraksi buatan sudah mulai dikembangkan, menambahkan atraksi yang asli dan alami. Berbagai barang dan jasa impor sudah menjadi keharusan termasuk tenaga kerja asing untuk mendukung perkembangan industri pariwisata yang pesat.

d. Consolidation adalah tahapan yang menunjukkan pariwisata sudah dominan dalam struktur ekonomi daerah dan dominasi ekonomi ini dipegang oleh jaringan internasional atau major chains and franchise. Jumlah kunjungan wisatawan masih naik, tetapi pada tingkat yang lebih rendah. Pemasaran semakin gencar dan diperluas untuk mengisi berbagai fasilitas yang sudah dibangun. Fasilitas lama sudah mulai ditinggalkan atau tidak laku.

e. Stagnation adalah tahapan yang menunjukkan kapasitas berbagai faktor telah terlampaui (di atas daya dukung, carrying capacity) sehingga menimbulkan masalah ekonomi, sosial, dan lingkungan. Kalangan industri sudah mulai bekerja berat untuk memenuhi kapasitas dari fasilitas yang dimiliki, khususnya dengan mengharapkan repeater guests atau wisata konvensi/bisnis. Pada fase ini, atraksi buatan sudah mendominasi atraksi asli-alami (baik budaya maupun alam), citra awal sudah meluntur, dan destinasi tidak lagi populer.

f. Decline adalah tahapan beralihnya wisatawan ke destinasi baru atau pesaing dan yang tinggal hanya 'sia-sia', khususnya wisatawan yang datang untuk berakhir pekan. Banyak fasilitas wisata sudah beralih atau dialihkan fungsinya untuk kegiatan non-pariwisata sehingga destinasi semakin tidak menarik bagi wisatawan. Partisipasi lokal mungkin meningkat lagi, terkait dengan harga yang merosot turun dengan melemahnya pasar. Destinasi bisa berkembang menjadi destinasi kelas rendah (a tourism slum) atau sama sekali secara total kehilangan diri sebagai destinasi wisata. g. Rejuvenation adalah tahapan perubahan secara dramatis sebagai hasil usaha dari berbagai pihak untuk menuju perbaikan atau peremajaan. Peremajaan ini bisa terjadi karena adanya inovasi dalam pengembangan produk baru, atau menggali dan memanfaatkan sumber daya alam dan budaya yang sebelumnya belum dimanfaatkan.

Penelitian ini menggunakan pendekatan kualitatif yang menggali secara mendalam informan terkait topik yang dikaji baik melalui wawancara maupun focus group discussion (FGD). Pengumpulan data menggunakan data kuantitatif dan data kualitatif yang bersumber baik dari observasi, wawancara, studi literatur, dokumentasi, maupun FGD yang kemudian dijabarkan dalam kualitatif. Data dijabarkan secara deskriptif dengan menggunakan tabel dan gambar.

Data kualitatif dalam penelitian ini berupa uraian keadaan kondisi fisik dari Desa Carangsari, fasilitas yang tersedia, monografi desa dan kebijakan terkait desa wisata di Kabupaten Badung, sedangkan data kuantitatif berupa data luas Desa Carangsari, jarak lokasi penelitian dari berbagai fasilitas umum seperti bandar udara, stasiun kereta, terminal dan hotel, termasuk data demografis, topografis, dan geografis.

Data primer dalam penelitian ini adalah kondisi fisik Desa Carangsari dan keadaan atraksi wisata yang diperoleh melalui observasi. Selain itu, juga ada informasi mengenai sejarah Desa Carangsari, perkembangan pariwisata, tradisi serta partisipasi masyarakat lokal di Desa Carangsari yang didapat dari narasumber melalui wawancara dan FGD. Sementara itu, data sekunder yang didapatkan berupa brosur pariwisata Kabupaten Badung terkait Desa Carangsari, kebijakan pariwisata di Kabupaten Badung, profil Desa Carangsari, dan informasi tambahan dari media elektronik maupun cetak.

Wawancara dilakukan untuk mengetahui bentuk, proses, dan manfaat partisipasi yang terjadi di Desa Wisata Carangsari, proses partisipasi dalam setiap tahapan pengembangan Desa Wisata Carangsari, manfaat yang diterima masyarakat dari partisipasi yang selama ini dilakukan, menggali faktor-faktor yang menyebabkan rendahnya 
partisipasi serta model partisipasi masyarakat dalam pengembangan Desa Wisata Carangsari.

Penentuan informan dalam wawancara menggunakan metode purpossive sampling. Adapun informan dalam penelitian ini adalah para pemangku kepentingan terkait, yakni Kepala Desa Carangsari, Ketua Kelompok Sadar Wisata Desa Carangsari, Kepala Bidang Daya Tarik Wisata Kabupaten Badung, Kepala Seksi Pengembangan Kawasan Pariwisata Kabupaten Badung, Mantan Kepala Desa Carangsari saat Desa Carangsari ditunjuk menjadi desa wisata, Maestro Topeng Tugek, Direktur Operasional True Bali Experience, pengusaha lokal Alam Tirta Outbound, pelaku desa wisata, dan peneliti desa wisata.

Observasi yang dilakukan dalam penelitian ini adalah melihat kondisi kepariwisataan serta partisipasi masyarakat Desa Carangsari dalam pengembangan desa wisata. Sepanjang pengamatan yang dilakukan sejak tanggal 1 Agustus sampai 1 November 2017 di Desa Carangsari, pariwisata memang hanya berjalan di lokasi industri saja dengan berbagai kegiatan wisata yang ditawarkan, seperti wisata arung jeram ( rafting), wisata menaiki gajah, serta outbound. Pengamatan dilakukan di Desa Carangsari dan beberapa industri pariwisata, seperti True Bali Experience, Mega Rafting, My Adventure Rafting serta Alam Tirta Outbound. Hal ini dikarenakan ada beberapa industri yang tidak mengizinkan peneliti mengamati langsung.

Hal menarik bahwa sebagai desa wisata, di lokasi masyarakat Desa Carangsari menjalankan aktivitasnya sehari-hari seperti tidak ada kegiatan wisata, terkecuali di lokasi industri pariwisata. Monumen Perjuangan I Gusti Ngurah Rai sangat sepi pengunjung dan potensi unik desa yang belum tergarap optimal akan dibahas lebih dalam bagian selanjutnya.

Dokumentasi dilakukan untuk memperoleh informasi tambahan terkait partisipasi masyarakat dalam bentuk foto dan video yang berkaitan dengan informasi dan data penelitian di Desa Carangsari. Data berupa peta dan dokumen terkait desa wisata seperti Rencana Induk Pengembangan Pariwisata Daerah Badung dan Peraturan Bupati Badung Nomor 47 Tahun 2010 tentang Desa Wisata di Kabupaten Badung diperoleh dari Dinas Pariwisata Daerah Kabupaten Badung khususnya pada bidang daya tarik wisata.

Data-data tersebut dapat dengan mudah dikumpulkan karena dukungan semua pihak yang ingin melihat hasil penelitian ini sebagai referensi dan masukan dalam pengembangan desa wisata di Kabupaten Badung terutama mengenai partisipasi masyarakat lokal dalam pengembangan Desa Wisata Carangsari di Kecamatan Petang, Kabupaten Badung.

FGD merupakan suatu proses pengumpulan informasi mengenai suatu masalah tertentu yang sangat spesifik (Irwanto, 2007: 1-2). Dalam penelitian ini, FGD berfokus pada rumusan masalah dengan topik penelitian yakni partisipasi masyarakat lokal dalam pengembangan Desa Wisata Carangsari di Kecamatan Petang, Kabupaten Badung. FGD tersebut diadakan pada tanggal 31 Agustus 2017. Adapun peserta FGD terdiri dari akademisi, pemerintah, swasta, dan tokoh masyarakat. Secara terinci stakeholders yang hadir adalah Kepala Desa Carangsari (I Nengah Artawa), Ketua Kelompok Sadar Wisata (I Nyoman Diana), Kepala Seksi Pengembangan Kawasan Pariwisata Kabupaten Badung (Ni Nyoman Ayu Nalayani), pelaku desa wisata (Mendra Astawa), dan peneliti desa wisata (Anak Agung Gede Raka Dalem).

\section{HASIL DAN PEMBAHASAN}

Desa Carangsari terletak di Kecamatan Petang, Kabupaten Badung, terdiri dari tiga desa adat dan sepuluh banjar dinas. Desa Carangsari ditetapkan sebagai desa wisata melalui Peraturan Bupati Badung No. 47 Tahun 2010 tentang Desa Wisata di Kabupaten Badung yang di dalamnya tertuang 11 desa wisata. Secara ringkas, Tabel 1 menjabarkan kondisi perkembangan kepariwisataan di Desa Wisata Carangsari. Dalam tabel ini dapat dilihat bahwa kepariwisataan di Desa Carangsari baru berkembang meskipun sudah dimulai sejak 1994. 
Tabel 1. Perkembangan Desa Wisata Carngsari

Tahapan (Jangka Waktu)

Momentum Penting

Berdirinya usaha pariwisata Ayung River Rafting oleh investor lokal yakni Anak Agung Alit Yudha yang menjadi cikal bakal terbentuknya True Bali Experience.

Perintisan Pertama kalinya wisatawan datang ke Desa Carangsari (1994-2010) untuk berwisata dan masyarakat lokal dipekerjakan. Menjamurnya usaha pariwisata lainnya, seperti Mega Rafting, Bahama Rafting, My Adventure Rafting, Angkasa Rafting, dan Alam Tirta Outbound.
Karakteristik

Masyarakat melihat pariwisata sebagai lahan pekerjaan dengan menjadi pekerja di usaha pariwisata yang ada.

Pemerintah daerah mulai memperhatikan Desa Carangsari dengan terbentuknya kelompok sadar wisata dengan program pelatihan bahasa Inggris.

Masyarakat mulai sadar akan potensi sebagai desa wisata tetapi sampai saat ini tetap sebagai pekerja.

Sumber: diolah dari wawancara lapangan 2017.

Tabel 1 menjelaskan bahwa kepariwisataan di Desa Carangsari baru berkembang, tetapi sudah dimulai sejak 1994. Selanjutnya, penelitian ini mengungkap partisipasi masyarakat lokal dalam tiga pokok pembahasan sebagai berikut.

\section{Bentuk, Proses dan Manfaat Partisipasi Masyarakat Lokal dalam Pengembangan Desa Wisata Carangsari}

Partispasi di Desa Wisata Carangsari tergolong pasif dengan bentuk consultation yang partisipasinya berjalan sebatas pencitraan atau bersifat semu, berdasarkan teori Arnstein (1969) serta didukung dengan wawancara di lapangan. Masyarakat tidak terlibat dalam terwujudnya Desa Wisata Carangsari seperti yang ditunjukkan Tabel 2. Hal ini perlu menjadi perhatian serius untuk segera ditanggulangi agar masyarakat dapat lebih aktif dan mengoptimalkan manfaat yang diperoleh.
Kesimpulan yang didapat pada masingmasing tahapan, partisipasi tidak berjalan sesuai dengan indikator. Perkembangan Desa Wisata Carangsari selama tujuh tahun terakhir berjalan di tempat dan upaya baru mulai dilakukan di tahun ini dengan anggaran pada tahun 2018. Menurut keterangan Ida Ayu Anggreni Pudja selaku Kepala Bidang Daya Tarik Wisata di lingkungan Dinas Pariwisata Kabupaten Badung, bahwa selama ini memang desa wisata belum tergarap secara maksimal sehingga ke depan, anggaran yang sudah pasti ada adalah untuk tahun 2018 . Mengingat hal ini diawali oleh investor lokal kemudian pemerintah memberikan 'label' desa wisata, membuat masyarakat menjadi kurang aktif sehingga elemen partisipasi hanya menjadi sebatas pekerja seperti pada Gambar 1. Hal ini juga dikarenakan hanya yang bekerja di industri pariwisata yang mendapatkan manfaat dari pariwisata di Desa Carangsari dan hanya manfaat yang bersifat ekonomi. 
Tabel 2. Tahapan Partisipasi Masyarakat Lokal dalam Pengembangan Desa Wisata Carangsari

\begin{tabular}{|c|c|c|}
\hline $\begin{array}{l}\text { Tahapan Parti- } \\
\text { sipasi }\end{array}$ & Indikator Partisipasi Masyarakat & $\begin{array}{l}\text { Kondisi Riil Partisipasi Masyarakat di Desa Wisata } \\
\text { Carangsari }\end{array}$ \\
\hline Perencanaan & $\begin{array}{l}\text { Survei lapangan } \\
\text { Penyusunan rencana tapak } \\
\text { Penyusunan anggaran dan sum- } \\
\text { ber anggaran } \\
\text { Perencanaan SDM }\end{array}$ & $\begin{array}{l}\text { Masyarakat tidak dilibatkan pada tahapan perenca- } \\
\text { naan di seluruh indikator. Survei lapangan dilakukan } \\
\text { oleh DISPARDA Badung hanya pada pegawai kantor } \\
\text { Desa Carangsari. }\end{array}$ \\
\hline $\begin{array}{l}\text { Pelaksanaan } \\
\text { Pembangunan }\end{array}$ & $\begin{array}{l}\text { Pembangunan prasarana } \\
\text { Pelaksanaan pembangunan }\end{array}$ & $\begin{array}{l}\text { Masyarakat dilibatkan dalam pelaksanaan } \\
\text { pembangunan prasarana, seperti pada pemugaran } \\
\text { Monumen Perjuangan I Gusti Ngurah Rai dan pem- } \\
\text { bangunan Tugek House Activity. Partisipasi masyara- } \\
\text { kat berupa tenaga. }\end{array}$ \\
\hline Pengelolaan & $\begin{array}{l}\text { Perekrutan SDM } \\
\text { Pengorganisasian } \\
\text { Promosi }\end{array}$ & $\begin{array}{l}\text { Pengelolaan kurang melibatkan masyarakat lokal pada } \\
\text { indikator promosi, sedangkan dua indikator lainnya } \\
\text { telah melibatkan masyarakat tetapi belum optimal. } \\
\text { Pengorganisasian sebatas pada pembentukan POK- } \\
\text { DARWIS dan perekrutan SDM di jejaring desa wisata } \\
\text { tingkat kabupaten Badung hanya satu orang. }\end{array}$ \\
\hline Evaluasi & $\begin{array}{l}\text { Penelitian dan pengembangan } \\
\text { Pelaporan }\end{array}$ & $\begin{array}{l}\text { Hanya pada tahun } 2017 \text { tahapan evaluasi melibatkan } \\
\text { masyarakat dan dilakukan setelah tujuh tahun berjalan } \\
\text { pasca penetapan. Masyarakat berpartisipasi dalam } \\
\text { memberikan ide dan tanggapan dalam penelitian yang } \\
\text { dilakukan UNUD. }\end{array}$ \\
\hline
\end{tabular}

Sumber: diolah dan diadaptasi dari Parisukmana dan Mulyadin, (2001, 39-40).

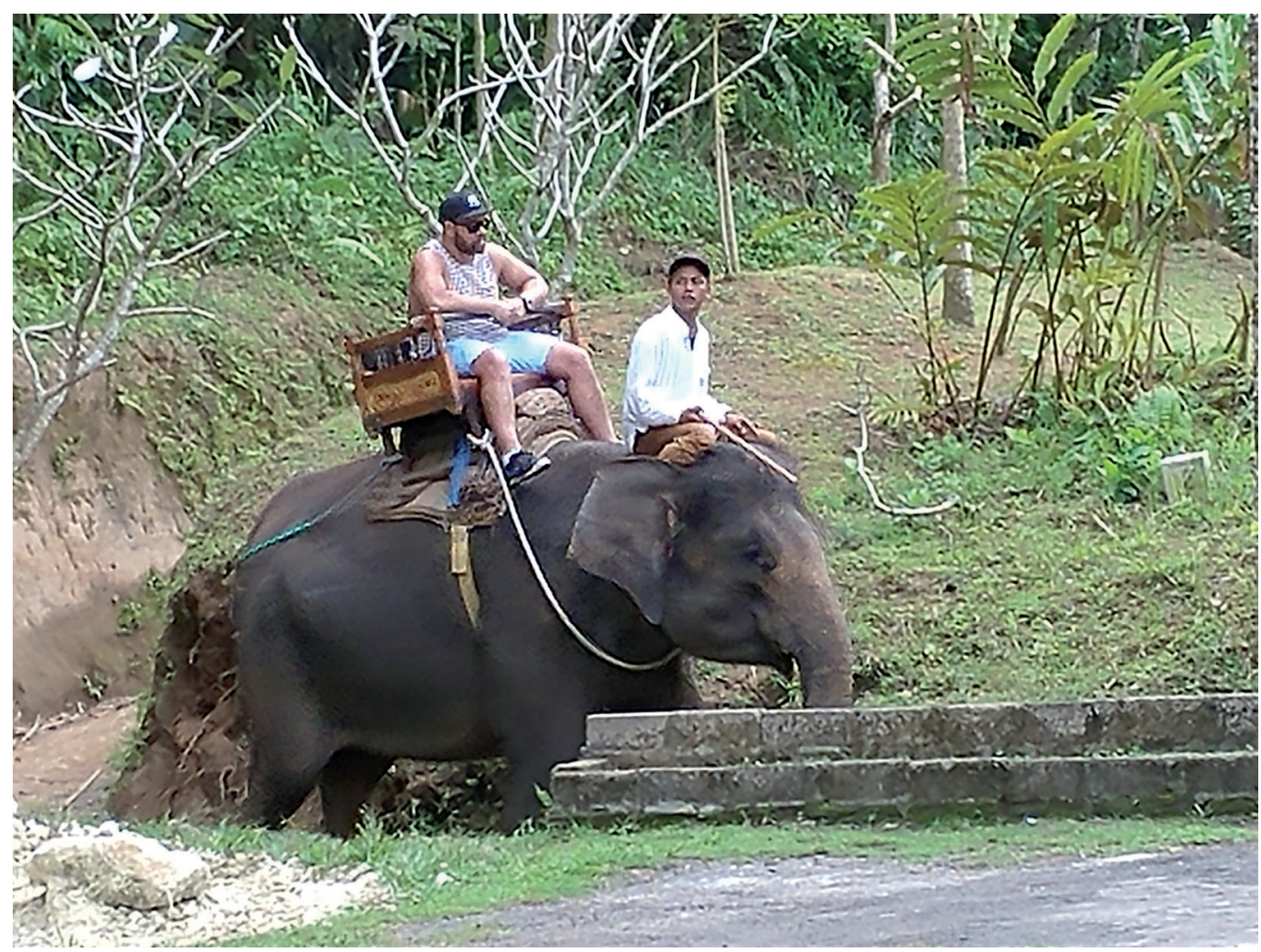

Sumber foto: penulis, 2017

Gambar 1. Wisatawan Menikmati Produk Wisata Elephant Ride yang Terkenal tetapi Bukan Asli dari Desa Carangsari 


\section{Faktor-Faktor yang Memengaruhi Rendahnya Partisipasi Masyarakat Lokal dalam Pengembangan Desa Wisata Carangsari}

Jika diamati secara langsung di lapangan menggunakan teori Irritation Index (Doxey, 1975) mengenai tanggapan masyarakan terkait kehadiran pariwisata saat ini, Desa Carangsari cenderung mengarah kepada fase euphoria. Fase dimana masyarakat melakukan kontak langsung/ interaksi dengan wisatawan tetapi tidak intens dan menganggap pariwisata sebagai sumber pendapatan dan investasi atau peluang usaha. Masyarakat menerima kepariwisataan tetapi hanya sebatas melihatnya dalam keuntungan ekonomi yang menyebabkan partisipasi mereka kurang. Penelitian ini menemukan faktor yang memengaruhi rendahnya partisipasi tersebut terbagi menjadi faktor internal dan faktor eksternal.

Faktor internal yakni faktor dalam lingkup desa sehingga permasalahan tersebut ada dalam desa tersebut, di antaranya 1) rendahya pemahaman masyarakat terkait desa wisata yang disebabkan oleh kurangnya sosialisasi. Hal itu mengakibatkan pemahaman yang terbentuk tidak satu visi sehingga partisipasi masyarakat menjadi kurang; 2) belum adanya badan atau lembaga pengelola desa wisata yang mampu membuat program dan arah pengembangan desa wisata menjadi jelas serta memiliki kemampuan untuk mengatur harga, jika ke depan Desa Wisata Carangsari ingin berkompetisi pada kualitas pelayanan dan daya tarik wisata alih-alih harga; 3) kurangnya sumber daya manusia di bidang pariwisata untuk kegiatan wisata lainnya, seperti kemampuan mengelola akomodasi, kemampuan menyajikan makanan yang higienis serta mengatasi wisatawan atau tamu yang complain; 4) belum adanya pemetaan produk unggulan desa wisata sehingga potensi lokal tidak terangkat, menjadikan masyarakat tidak menguasai daya tarik yang ditawarkan selama ini. Idealnya, apa yang dimiliki masyarakat sebagai potensi lokal dikembangkan menjadi desa wisata kemudian dipetakan produk unggulannya sehingga berbeda dari desa wisata lainnya.

Faktor eksternal yaitu hal-hal yang berada di luar kemampuan Desa Carangsari, terdiri dari 1) belum adanya kajian terhadap desa wisata oleh akademisi untuk mengembangkan desa wisata agar sesuai dengan prinsip pariwisata berkelanjutan serta pariwisata berbasis masyarakat yang manfaatnya sebesar-besarnya untuk masyarakat; 2) rendahnya sumber dana dari daerah Kabupaten Badung untuk pengembangan desa wisata yang menyebabkan partisipasi masyarakat menjadi kurang serta mengalami kendala dalam akses permodalan untuk setiap kegiatan yang akan dicanangkan; 3) belum adanya program pemberdayaan sumber daya manusia untuk pengembangan desa wisata oleh lembaga profesional untuk meningkatkan keterampilan masyarakat dalam menangani wisatawan; 4) belum adanya pemasaran yang komprehensif untuk mendatangkan wisatawan dari Dinas Pariwisata Daerah (Disparda) ataupun swasta, seperti melakukan table top meeting khusus untuk desa wisata serta program bermalam di desa wisata yang dapat digabungkan dengan promo hotel ataupun vila sehingga semakin banyak wisatawan yang datang ke desa wisata, secara tidak langsung mendorong partisipasi masyarakat lokal karena melihat hasil nyata dari pariwisata di desanya.

\section{Model Partisipasi Masyarakat Lokal dalam Pengembangan Desa Wisata Carangsari}

Jika mengamati perkembangan Desa Carangsari sampai saat ini melalui observasi, wawancara, dokumentasi, serta FGD maka desa ini dapat dikatakan telah berada pada fase involvement menurut teori Tourism Area Life Cycle (Butler, 1980). Pada fase ini, fasilitas pariwisata mulai dibangun dan dipersiapkan untuk wisatawan dan terjadinya pola perubahan ekonomi masyarakat sebagai bentuk respons terhadap perubahan yang terjadi seperti dibangunnya stage di puri Topeng Tugek Carangsari yang direncanakan sebagai starting point dari kawasan pariwisata kluster Petang. Masyarakat lokal juga menjadi pekerja pariwisata yang pada awalnya adalah petani, tetapi ada juga yang menjalankan keduanya. Pemerintah juga mulai memperhatikan desa wisata dengan membuat kebijakan Peraturan Daerah Kabupaten Badung Nomor 17 Tahun 2016 tentang Rencana Induk Pembangunan Kepariwisataan Tahun 2017-2025. 
Berdasarkan posisi yang dimiliki oleh Desa Wisata Carangsari, model alternatif yang ditawarkan menggunakan pendekatan bottom-up yaitu merangkai alur ide yang bangkit dari masyarakat bersama pemerintah dan akademisi dalam mengembangkan potensi lokal menjadi daya tarik wisata alam dan budaya. Tujuannya agar lahir Desa Wisata Carangsari yang ideal dan dikelola oleh Badan Pengelola Desa Wisata Carangsari dengan anggota perwakilan dari masyarakat, khususnya lembaga adat, POKDARWIS, dan BUMDES. Pengelolaan Desa Wisata Carangsari dari masyarakat diharapkan mampu memberikan manfaat berupa kesejahteraan ekonomi, revitalisasi budaya lokal, dan konservasi lingkungan sebagaimana ditunjukkan pada Gambar 2.

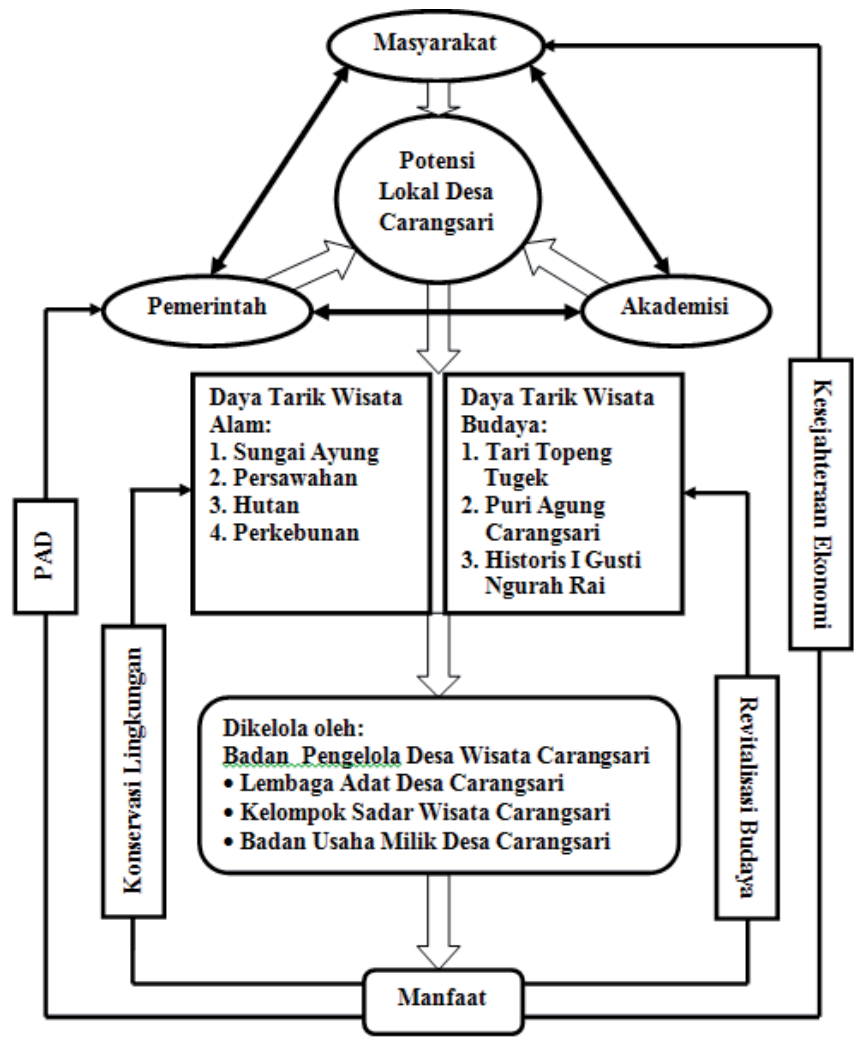

Sumber: diolah dan diadaptasi dari Pujaastawa, Wirawan, dan Adhika $(2005,131)$

Gambar 2. Model Partisipasi Masyarakat Lokal dalam Pengembangan Desa Wisata Carangsari (versi Alternatif)

Berdasarkan Gambar 2, dapat dijelaskan bahwa partisipasi masyarakat yang ideal dalam pengembangan Desa Wisata Carangsari adalah masyarakat menjadi aktor kunci yang memiliki potensi lokal dan kemudian mengembangkan- nya bersama dengan akademisi dan pemerintah. Masyarakat berpartisipasi melalui buah pikiran, tenaga, ataupun material dalam memaksimalkan potensi lokal yang belum tergarap yang akan menjadi daya tarik wisata sebagaimana konsep pariwisata berbasis masyarakat. Konsep yang mengedepankan bottom-up yaitu pengembangan kepariwisataan yang dimulai dari inisiatif masyarakat yang menyadari potensi lokal yang dimiliki agar dikelola dan dikembangkan oleh masyarakat, kemudian memberikan manfaat konservasi lingkungan, revitalisasi budaya, dan peningkatan ekonomi bagi masyarakat.

Potensi lokal yang dimiliki oleh masyarakat akan berkembang secara optimal apabila dibantu oleh kontribusi dua elemen yang lain, yakni elemen pemerintah dan elemen akademisi. Di satu sisi, pemerintah memiliki fungsi sebagai fasilitator dan regulator dapat berkontribusi dalam penyempurnaan infrastruktur serta fasilitas penunjang untuk mewujudkan desa wisata. Infrastruktur yang dimaksud adalah kelistrikan, jalan yang baik, kelancaran jaringan komunikasi, akses internet, serta penunjuk arah ke desa Carangsari. Fasilitas kepariwisataan yang dimaksud seperti homestay, pusat informasi pariwisata, toilet untuk wisatawan, serta parkir yang memadai. Potensi lokal yang akan dibentuk menjadi desa wisata sangat membutuhkan pengakuan dan perlindungan hukum untuk memastikan keberlanjutan serta manfaat yang penuh untuk masyarakat di masa depan.

Pemerintah yang dimaksud adalah pemerintah Kabupaten Badung, khususnya Dinas Pariwisata Daerah Badung yang bersinggungan langsung dengan desa wisata, serta Pemerintah Desa Carangsari sebagai perpanjangan tangan dari kabupaten. Pendampingan dan evaluasi perlu dilakukan secara berkala untuk memfasilitasi ide dan gagasan dari masyarakat sehingga mereka berpartisipasi secara aktif dan mengetahui bagaimana cara mengakses program-program yang membantu dalam pengembangan potensi lokal menjadi desa wisata serta sumber dana yang sesuai sehingga mengurangi masalah administrasi yang menjadi penghambat dalam birokrasi.

Di sisi lain, akademisi berkontribusi melalui unit pengabdian masyarakat dalam melakukan 
kajian, penelitian, serta penyuluhan terkait desa wisata. Kajian seperti analisis potensi lokal untuk menjadi desa wisata, strategi pengembangan desa wisata, strategi pemasaran desa wisata, motivasi wisatawan yang berkunjung ke desa wisata, persepsi wisatawan terkait desa wisata, analisis kebijakan desa wisata serta penelitian lainnya untuk membantu pengembangan potensi lokal menjadi desa wisata. Akademisi yang dimaksud adalah perguruan tinggi yang menyelenggarakan program pariwisata, seperti Fakultas Pariwisata Universitas Udayana, Jurusan Pariwisata Politeknik Negeri Bali, Sekolah Tinggi Pariwisata Nusa Dua Bali, dan perguruan tinggi lainnya. Pengabdian yang dilakukan agar sesuai dengan kebutuhan dari masyarakat sehingga kontribusi elemen ini menyempurnakan potensi lokal yang akan dikembangkan menjadi desa wisata.

Masyarakat, pemerintah, dan akademisi bersinergi dalam mengembangkan potensi lokal menjadi daya tarik wisata unggulan dengan karakter yang berbeda dari desa wisata di Kabupaten Badung. Daya tarik wisata yang dikembangkan dari potensi berupa daya tarik wisata alam dan wisata budaya. Daya tarik wisata alam adalah keindahan dan panorama alam desa yang menjadi magnet bagi wisatawan. Desa Wisata Carangsari memiliki Sungai Ayung yang terkenal akan wisata arung jeramnya, persawahan sebagai identitas desa di Bali dengan subaknya, hutan yang berpotensi untuk outbound dan air soft gun, serta perkebunan yang ditumbuhi cokelat, kelapa, dan berbagai buah lokal yang menambah nuansa perdesaan.

Daya tarik wisata budaya adalah kekayaan budaya dan keunikan yang dimiliki oleh suatu destinasi. Desa Wisata Carangsari memiliki Tari Topeng Tugek yang sangat khas dan menjadi identitas Desa Carangsari, Puri Agung Carangsari yang masih menjaga arsitektur Bali, serta kisah historis I Gusti Ngurah Rai sebagai pahlawan nasional. Apabila seluruh kekayaan budaya tadi dikemas dengan baik, Desa Wisata Carangsari dapat memunculkan identitasnya yang khas dan unik yang membedakannya dari desa wisata lain di Kabupaten Badung. Daya tarik wisata alam dan budaya ini kemudian dikelola oleh Badan Pengelola Desa Wisata Carangsari.
Badan Pengelola Desa Wisata Carangsari adalah lembaga yang memiliki legalitas melalui surat keputusan bupati dan berfungsi mengelola Desa Wisata Carangsari. Anggotanya terdiri dari perwakilan masyarakat Carangsari khususnya lembaga adat Desa Carangsari, kelompok sadar wisata Desa Carangsari, dan Badan Usaha Milik Desa Carangsari. Badan tersebut bertugas mengatur dan menetapkan harga paket wisata, program pengembangan serta koordiansi dengan stakeholder pariwisata untuk membahas perkembangan dan permasalahan Desa Wisata Carangsari. Pemangku kepentingan atau stakeholder pariwisata yang dimaksud adalah Dinas Pariwisata Badung, akademisi dari perguruan tinggi pariwisata, tokoh masyarakat, media dan asosiasi di bidang pariwisata khususnya terkait desa wisata.

Daya tarik wisata yang dikelola oleh Badan Pengelola Desa Wisata Carangsari merupakan bentuk dari partisipasi masyarakat yang secara aktif mulai dari perencanaan, pengorganisasian, pengelolaan, dan evaluasi dari masyarakat, oleh masyarakat, dan untuk masyarakat. Manfaat dari model alternatif ini diharapkan mampu meningkatkan partisipasi masyarakat lokal sehingga dapat meningkatkan kesejahteraan ekonomi serta merevitalisasi budaya lokal. Revitalisasi yang dimaksud seperti pelestarian dan pengembangan Tari Topeng Tugek ataupun pemanfaatan Puri Agung Carangsari sebagai wisata puri serta konservasi lingkungan agar Sungai Ayung, hutan, persawahan dan perkebunan yang dimiliki tetap terjaga sehingga kegiatan wisata yang berlangsung dapat dinikmati kembali oleh masyarakat Desa Carangsari. Pemerintah juga memperoleh manfaat dari suksesnya Desa Wisata Carangsari melalui penerimaan pajak Pendapatan Asli Daerah (PAD) yang dapat digunakan untuk membenahi infrastruktur serta program-program pemberdayaan masyarakat.

Masyarakat desa Carangsari tetap mengawasi dan mengevaluasi kinerja dari Badan Pengelola Desa Wisata Carangsari agar tidak menyimpang dari fungsi yang telah ditetapkan. Laporan pertanggungjawaban dilakukan secara berkala pada musyawarah desa sehingga tercermin budaya transparansi, akuntabilitas, dan profesionalitas 
guna mewujudkan Desa Wisata Carangsari yang lebih baik. Model ini juga mengharapkan Desa Wisata Carangsari yang dikenal ke depannya adalah desa wisata yang menawarkan aktivitas kehidupan di desa yang dibalut dengan berbagai produk lokal dan dikemas dengan baik. Partisipasi masyarakat lokal menjadi kunci dalam mengedepankan budaya lokal yang menjadi magnet utama untuk menarik wisatawan berkunjung ke desa. Prasiasa $(2012,89)$ menjelaskan adanya perbedaan ruang, waktu, cara, dan keadaan pengemasan sepuluh elemen budaya, yakni kerajinan, tradisi, sejarah dan tempat/daerah, arsitektur, makanan lokal/tradisional, seni musik, cara hidup masyarakat, agama, serta bahasa dan pakaian lokal/tradisional. Elemen-elemen tersebut dapat menimbulkan diversifikasi produk wisata yang ditawarkan kepada wisatawan. Produk wisata tersebut dapat ditawarkan baik dalam bentuk terpisah maupun produk wisata yang berbentuk paket wisata (package tour).

Faktor kunci dari pembangunan pariwisata berbasis masyarakat adalah menjaga keseimbangan dan kesesuaian di antara lingkungan hidup dan kepuasan pengunjung melalui inisiatif masyarakat lokal. Hal ini karena dalam pariwisata berbasis masyarakat, potensi lokal yang menjadi penekanan juga digunakan masyarakat untuk kesejahteraannya sehingga perlu dijaga kesinambungannya. Pembangunan pariwisata berbasis masyarakat pada berbagai bidang membutuhkan syarat mutlak yaitu masyarakat sebagai pelaku pembangunan harus menguasai substansi pembangunan yang akan dilaksanakan. Pemahaman konsep pembangunan pariwisata sangat penting artinya bagi masyarakat yang akan melaksanakan pembangunan sebagai persiapan diri untuk melaksanakan pembangunan tersebut.

Model ini dibuat untuk mengarahkan masyarakat akan pentingnya partisipasi mereka sebagai bagian dari pembangunan pariwisata berbasis kerakyatan. Memperhatikan model tersebut diharapkan dapat membantu masyarakat lokal, Pemerintah Desa Carangsari serta Pemerintah Kabupaten Badung dalam menentukan langkah sehingga kebijakan yang akan dikeluarkan maupun program yang dianggarkan sesuai dengan kebutuhan masyarakat.

\section{PENUTUP}

Penelitian ini mengungkap partisipasi masyarakat yang terjadi di Desa Wisata Carangsari di Kecamatan Petang, Kabupaten Badung yang secara keseluruhan rendah dengan bentuk konsultasi yakni semu dan pasif. Masyarakat tidak terlibat dalam proses pengembangan desa wisata serta hanya manfaat ekonomi yang diperoleh. Hal ini mengungkap suatu kebaruan yakni tidak semua desa wisata masyarakatnya berpartisipasi. Oleh karena itu, Pemerintah Desa Carangsari sebagai lembaga yang memiliki kekuasaan di desa dengan dana yang cukup banyak dari program dana desa saat ini diharapkan mampu membentuk badan pengelola desa wisata serta mewadahi aspirasi masyarakat. Caranya dengan membentuk forum bekerja sama dengan para akademisi dalam memilah persoalan terutama terkait desa wisata dalam upaya meningkatkan partisipasi masyarakat. Pemerintah desa agar lebih aktif dalam mencari "partner" yang berasal dari instistusi pendidikan, perusahaan ataupun LSM dalam membantu pengembangan desa wisata sehingga meningkatkan partisipasi masyarakat.

Pemerintah Kabupaten Badung melalui Dinas Pariwisata Daerah yang menjadi ujung tombak kepariwisataan di Badung agar memfasilitasi setiap desa wisata untuk beraudiensi dengan pihak-pihak terkait yang diharapkan dapat memberikan solusi dalam memecahkan permasalahan serta menciptakan program yang dibutuhkan oleh desa tersebut. Dengan demikian, masyarakat desa dapat lebih aktif berpartisipasi dan mampu mandiri. Model alternatif yang diformulasikan agar ditindaklanjuti dengan kegiatan uji model dengan melibatkan masyarakat dan segenap stakeholders. Dalam kegiatan uji model dilakukan monitoring dan evaluasi yang selanjutnya dilakukan penyempurnaan sehingga terbentuk model yang baku.

Selanjutnya adalah peran aktif dari masyarakat sendiri yang tergerak untuk berpartisipasi dalam mewujudkan Desa Wisata Carangsari berbasis potensi lokal. Sosialisasi dari pemerintah, kajian dari akademisi serta pelatihan dari asosiasi pariwisata akan menstimulus partisipasi masyarakat sehingga tercipta kreasi produk wisata yang memiliki keunggulan dan menjadi ciri khas Desa Wisata Carangsari. 


\section{DAFTAR PUSTAKA}

Afifuddin, M. M. (2009). Metodologi penelitian kualitatif. Bandung: CV Pustaka Setia.

Antara, M., \& Arida, I. N. S. (2015). Panduan pengelolaan desa wisata berbasis potensi lokal. Denpasar: Konsorsium Riset Pariwisata Universitas Udayana.

Ardika, I. W. (2015). Warisan budaya perspektif masa kini. Denpasar: Udayana University Press.

Arida, N. S. (2016). Dinamika ekowisata Tri Ning Tri di Bali. Denpasar: Pustaka Larasan.

Arnstein, S. R. (1969). A ladder of citizen participation. American Institute of Planners, 35(4), 216-224.

Astuti, S. K. (2012). Dampak sosio kultural masyarakat Dusun Krebet sebagai salah satu destinasi wisata perdesaan [Tesis]. Yogyakarta: Universitas Negeri Yogyakarta.

Beratha, N. L. S., Ardika, I. W., \& Dhana, I. N. (2010). Dari tatapan mata ke pelaminan sampai di Desa Pakraman: Studi tentang hubungan orang Bali dengan orang Cina di Bali. Denpasar: Udayana University Press.

Butler, R. W. (2011). Tourism area life cycle. Oxford: Goodfellow Publishers Ltd.

Cooper, C., Wanhill, S., Fletcher, J., Gilbert, D., \& Fyall, A. (1995). Tourism: Principles and practice. Malaysia: Longman Group Ltd.

Desa dan budaya dalam bingkai pariwisata. (2011). Jakarta: Pusat Penelitian dan Pengembangan Kepariwisataan.

Doxey, G. (1975). A causation theory of visitorresident irritants. Makalah dipresentasikan pada Methodology and Research Inferences Travel and Tourism Research Associations Sixth Annual Conference. San Diego, 8-11 September 1975.

Fahmi, Z., Hamzah, A., Muhammad, M., Yassin, S. M., Samah, B. A., Silva, J. L. D., \& Shaffril, H. A. M. (2013). Involvement in agro-tourism activities among communities in Desa Wawasan Nelayan Villages on the East Coast of Malaysia. Asian Social Science: Canadian Center of Science and Education, 9(2), 203-207.

GIZ. (2016). Buku panduan pengembangan desa wisata hijau. Jakarta Selatan: Asisten Deputi Urusan Ketenagalistrikan dan Aneka Usaha Kementerian Koperasi dan UKM Republik Indonesia.

Irwanto. (2007). Focus Group Discussion: Sebuah Pengantar Praktis. Jakarta: Yayasan Obor Indonesia.
Kode etik kepariwisataan dunia. (2010). Jakarta: Kementerian Kebudayaan dan Pariwisata.

Laksana, N. S. (2008). Bentuk-bentuk partisipasi masyarakat desa dalam program desa siaga di Desa Bandung Kecamatan Playen Kabupaten Gunung Kidul Daerah Istimewa Yogyakarta. Kebijakan dan Manajemen Publik, 1(1), 56-67.

Madiun, I. N. (2008). Partisipasi masyarakat lokal dalam pengembangan kawasan pariwisata Nusa Dua (Perspektif kajian budaya) [Disertasi]. Denpasar: Universitas Udayana.

Maneenetr, T., Naipinit, A., \& Tran, T. H. (2014). Guidelines to promote local community participation in developing agrotourism: A case study of Ban Mor Village, Sam Sung District, Khon Kaen Province, Thailand. Asian Social Science: Canadian Center of Science and Education, 10(9), 178-186.

Mowforth, M., \& Munt, I. (2009). Tourism and sustainability (Development, globalization and new tourism in the third world). Edisi ketiga. New York: Routledge, Taylor \& Francis Group.

Muganda, M., Sirima, A., \& Ezra P. M. (2013). the role of local communities in tourism development: Grassroots perspectives from Tanzania. Journal of Human Ecology, 41(1), 53-66.

Nalayani, N. N. A. H. (2015). Evaluasi dan strategi pengembangan desa wisata di Kabupaten Badung, Bali [Tesis]. Denpasar: Universitas Udayana.

Neumeier, S., \& Pollermann, K. (2014). Rural Tourism as promoter of rural development-prospects and limitations: Case study findings from a pilot project promoting village tourism. European Countryside: De Gruyter, 4(15), 270-296.

Parisukmana, S., \& Mulyadin, R. M. (2001). Pembangunan desa wisata: Pelaksanaan undangundang otonomi daerah. Info Sosial Ekonomi, 2(1), 37-44.

Prasiasa, D. P. O. (2012). Destinasi pariwisata berbasis masyarakat. Jakarta: Salemba Humanika.

Prasiasa, D. P. O., \& Widari, D. A. D. S. (2017). Desa wisata potensi dan strategi pengembangan. Denpasar: Pustaka Larasan.

Pujaastawa, I. B. G., Wirawan, I. G. P., \& Adhika, I. M. (2005). Pariwisata terpadu: Alternatif model pengembangan pariwisata Bali Tengah. Denpasar: Udayana.

Rai Utama, I. G. B., \& Mahadewi, N. M E. (2012). Metodologi penelitian pariwisata \& perhotelan. Denpasar: ANDI. 
Rizqina, F. (2010). Partisipasi masyarakat dalam implementasi kebijakan manajemen berbasis sekolah di Kecamatan Kalideres Kota Madya Jakarta Barat [Tesis]. Jakarta: Universitas Indonesia.

Salleh, N. H. M., Shukor, M. S., Othman, R., Samsudin, M., \& Idris, S. H. M. (2015). Factors of local community participation in tourismrelated business: Case of Langkawi Island. International Journal of Social Science and Humanity, 6(8), 565-571.

Spenceley, A. (2008). Responsible tourism. British: Dunstan House.

Undang-Undang Republik Indonesia Nomor 10 tentang Kepariwisataan. (2009). Jakarta: Pemerintah Republik Indonesia.

United Nations of World Tourism Organization. (2016). UNWTO tourism highlights 2016. Madrid: UNWTO.
Wanga, J. O., Hayombe, P. O., Agong, S. G., \& Mossberg, L. (2014). Stakeholder involvement in tourism destination development: A case of Dunga Beach and Wetland, Kisumu Country, Kenya. Journal of Arts and Humanities, 3(8), 13-27.

Weafer, D., \& Lawton, L. (2010). Tourism management. Edisi Keempat. Australia: John Wiley \& Sons Australia, Ltd.

Yulianie, F. (2015). Partisipasi dan pemberdayaan masyarakat dalam pengelolaan daya tarik wisata "Rice Terrace" Ceking, Gianyar, Bali. Jurnal Master Pariwisata, 2(1), 165-184.

Ziku, R. M. (2015). Partisipasi masyarakat Desa Komodo dalam pengembangan ekowisata di Pulau Komodo. Jurnal Master Pariwisata, 2(1), 1-21 
